\title{
New Norms of Online Teaching and Learning: Covid-19 Semester Experience for Universiti Malaysia Terengganu Students
}

\author{
Noor Rohana Mansor* \\ Asyraf Hj Ab Rahman \\ Azza J. Ahmad Tajuddin \\ Roswati Abd Rashid \\ Nurul Ain Chua \\ Centre for Fundamental and Continuing Education, \\ Universiti Malaysia, Terengganu, Malaysia \\ ${ }^{*}$ Corresponding Author
}

DOI: https://doi.org/10.36941/ajis-2021-0114

\section{Abstract}

The COVID-19 pandemic has affected the national education agenda at all levels of education. New Teaching and Learning (TEL) online norms have been executed except for specific academic programs and subjects only since 18 March 2020 when the Movement Control Order (MCO) was administered and continued to this day. To guarantee students' continuity of education without online TEL dropout, online face-to-face (Synchronous) or not face-to-face (Asynchronous) is now become the primary approach and method platform with many virtual education applications. Therefore, this research examined students' readiness to follow online teaching and learning and analysed the impact of online TEL on the national education agenda. This study involved 133 students of Diploma in Fisheries, Universiti Malaysia Terengganu, for the first semester of 2020-21. Data were obtained through a questionnaire using Google Form and presented to students by sharing links to their WhatsApp group in the final week of study. The questionnaire was adapted from several instruments related to various aspects of online TEL during the COVID-19 pandemic. The outcomes revealed that most students were among Gen-Z with digital literacy background. Thus, it was assisting them having a high level of readiness to face online TEL. In terms of the availability of device infrastructure, internet access, e-Learning, and computers, most (80\%) have mastered it. Only (20\%) have low proficiency due to limited experience using computers and gadgets due to family constraints and their literacy levels. The research conclusion recommends a consecutive enhancement in curriculum structure flexibility, delivery, evaluation; internet accessibility and digital gap, and self-motivation of students entering the era of the self-regulated learner. Transformation demands the strategic cooperation of various parties in educational institutions, government agencies, the private sector, NGOs, and people's leaders in the interest of the country's advancing education relevant to the era of global technology-oriented education and digital infrastructure.

Keywords: Pandemics, New Norms, Online Teaching and Learning 


\section{Introduction}

The year 2020 had imposed a drastic transformation in the country's education landscape and worldwide when the world was hit by the COVID-19 pandemic as declared by the World Health Organization (WHO) on 11 March 2020. Hence, Malaysia enforced the Movement Control Order (MCO) on 18 March 2020, extended to Conditional Movement Control Order (CMCO), Recovery Movement Control Order (RMCO), and Enhanced Movement Control Order (EMCO) in stages and by location. It continued even until 2021 when MCO 2.0 was declared to encounter COVID-19 which still shows active cases. Hence, all national educational institutions of primary, secondary and higher education institutions have been closed to break the chain of transmission of this dangerous pandemic and implemented standard operating procedures (SOP).

Therefore, T\&L has been carried out online until the end of 2020 and continues until now, except for certain academic programs and subjects. The spread of the COVID-19 pandemic and the orders and instructions that have been issued have established the importance of online teaching and learning systems involving information and communication technology (ICT) including mobile devices such as laptops and mobile phones as well as internet networks. This scenario is in line with the technology-based Revolution 4.o agenda and creates an education system that remains innovative and high-tech to the modern generation of students to survive their future as previously announced. Zhiyasheva et al. (2021) reported that developments in ICT enable more information services to be used in education applications and it is important for educators to adopt technology, show a positive attitude towards it in order to be able to use the developing technology and to integrate their lessons with technology in order to train individuals of the information society. Indeed, using technology is not a privilege but a necessity because technological developments affect the structure and functions of educational institutions (Zhiyasheva et al. 2021; Yuliya Murzo \& Natalia Chuvileva, 2021). Thus, UNESCO (United Nations Educational, Scientific and Cultural Organization) has also recommended using various technologies to ensure the continuity of learning to assure the education system does not hold even if the whole world is disturbed by this pandemic.

Nevertheless, to what extent are the educators and students willing to endure this shocking situation? The new educational norms influenced by the COVID-19 pandemic prompt awareness, realisation and immediate action towards change to remain relevant to the prevailing circumstance. The paradigm shifts the thinking from conventional to digitalisation, and all groups of educators must accept it at all levels of education. The education system needs change, innovation, and extensive creativity to improve the latest approaches, methods, techniques, and strategies to adapt to current realities. Indeed, this is a challenge that needs to be accepted positively, demands openness, go through with patience, and even be grateful for His wisdom of this tragedy for the good of students' future for more meaningful survival, and thus making the concept of education for all be fully realised. Plato was once stated that justice is a human virtue that makes a person self consistent and good while socially it is a social consciousness that makes a society internally harmonious and good (A. Rahman, W.Ibrahim, 2012).

In the effort to overcome this situation, online learning substitutes face-to-face interactions, becoming prevalent among academics and students. Struggles are faced with full strength and patience. Some are even depressed to support teaching and learning (T\&L), which experienced sudden change during the ongoing semester, but the responsibility must be continued. Whether blending or using Web 2.0, lecturers, and students must adapt to the current situation (Mohan Rathakrishnan, 2020). Delivering the responsibility of adapting to T\&L online is arduous, especially among senior educators, called the baby boomers' generation. It is especially evident when compared to the young educators who have been through the era of computer, and digital literacy since the beginning, namely generations $\mathrm{X}$ and $\mathrm{Y}$. Nevertheless, students among the Net generation or Gen-Z will only take a short time to adjust. They are among the digital literate; holding a self-oriented learning style; wisely accessing online learning mediums; and making their own decisions on appropriate technological tools to complete tasks well (Nurulrabihah Mat Noh et al., 2019). However, 
the application of T\&L online face-to-face (Synchronous) and non-face-to-face online (Asynchronous) necessitates skills and knowledge among educators and students. The process seems simple, but the challenge of educating remains for educators, students, and parents. The current T\&L process also takes place on a home-based learning basis when a work from home (WFH) session is applied.

The new norms of online T\&L have been continued to be observed to this day as they get habituated to it. The practice of undergoing T\&L online face-to-face or not face-to-face has become common with the experience that occurred, felt, and lived to perform the duties and responsibilities of educating. Various platforms and applications have been successfully used with self-effort through youtube and the like. Through intensive training of online workshops provided by the organisation, they have helped many educators strengthening the search for knowledge to continue the task and provide useful T\&L to students. Search trends have released evidence dated 16 April 2020 for the phrase 'Google Classroom' in Malaysia experienced a rise to second place globally, surpassing developed countries with more advanced e-learning systems and technologies.

T\&L typically done face-to-face in lecture halls has been replaced with online platforms such as Webex, Google Classroom, Google Meet, Microsoft Team, Edmodo, Zoom, Skype, WhatsApp, Facebook Live and Telegram. Various T\&L support applications for implementing activities and evaluations are also growing, such as Kahoot, Mentimeter, Powtoon, Screencast-O-Matic, Canva, Podcast, Quizziz, Socrative, Google Form, and Edpuzzle. Besides, the new norms of online T\&L also provide opportunities for students to continue teamwork and communicate via email and information sharing through Google Drive and the like.

The e-Learning platform is also intensified, including Massive Open Online Courses (MOOC), Open Learning, Moodle and Learning Management System (LMS). E-Learning makes it easier for students to access the T\&L materials of a course uploaded by lecturers online and train the values of self-learning. E-Learning has been introduced previously as one of the methods for educators to attract students and transform traditional teaching into technology-based teaching but not actively performed. Nowadays education has changed dramatically with the distinctive rise of e-learning. It is absolutely clear that the adoption of online learning will continue to persist during the postpandemic period (Yuliya Murzo \& Natalia Chuvileva, 2021).

Also, educators' role in dealing with online T\&L requires a lot of discipline and creativity to adapt the T\&L materials that are traditionally practised to the digitalisation needs of information and communication technology transformation. The readiness of educators includes; ready to commit to attitude change to comply with current needs; act immediately to plan strategies to improve selfprofessionalism for the enhancement of knowledge, competencies, capabilities, and skills in digital technology; and being able to master information and communication technology literacy especially e-Learning.

Therefore, this paper aimed to examine students' readiness to follow online teaching and learning and determined impact of online T\&L on the national education agenda on an ongoing basis. Research questions include: How are students prepared for online T\&L during the COVID-19 semester; What is the impact of online T\&L on the sustainability of the national education agenda? Its goal is to formulate appropriate views, needs, actions and strategies towards strengthening the online T\&L culture to continue post-pandemic education transformation and meet the needs of the RI 4.o agenda.

\section{Literature Review}

The Ministry of Education Malaysia (KPM) since 1999 has been working to develop an education system that implements learning processes based on information and communication technology (ICT). As a result, in the late 1990s, higher education institutions (IPT) development could be seen. Educational programs have integrated TMK in various forms using e-Learning, online learning or web-based learning. Public universities including Moodle have developed the Learning Management 
System (LMS) platform or Learning Management System and now e-Learning (UMT), e-Learning @ UTM (UTM), Learning Care / SPIn (UKM), MyLMS (oUM), i-Learn (UiTM), and Massive Open Online Courses (MOOCs). The development of information technology in T\&L is swift and stimulates the emergence of various applications. The integration of e-Learning in education facilitates the T\&L process (Zulikha \& Azlina, 2012) and provides space for students to access information and learning materials that have been uploaded by educators online. It is a transformation that has already taken place in educators' efforts to attract students from the traditional approach to technology-based T\&L.

In catering the needs of the adaptation and integration of technological advances in the latest education, the country's education landscape also plans for change in line with 21st-century education directly to the need for digital transformation in line with the Industrial Revolution 4.o. Planning under the Malaysian Education Development Plan (PPPM) 2013-2025 and the Malaysian Higher Education Development Plan (PPPM PT) 2015-2025, the government has already placed a shift and emphasis on the use of information technology, the transformation of teaching and learning processes. Among them is reflected in the ninth leap of global level online learning to transform the education system by utilising information technology to enhance the quality of learning in Malaysia on par with developed and world-class countries. It also considers facing the post-COVID-19 era with new norms when lecturers and students adapt to online learning, discursively impacting each institution's strategic plan while changing the existing direction. It is possible that the higher education system's atmosphere, particularly from the aspect of teaching and learning that is being implemented at this time, will continue to remain with the current changes for a long time (Mohamad Kadim Suaidi, 2020).

Thus, most previous studies confirmed that the accelerated evolution of technology had shown transformation and innovation with various creativity produced in T\&L. Norasmahani Hj Nor (2015) asserted that the ICT-based T\&L process covers a wide range of objectives and utilises an interactive approach to let the learning process to be carried out independently. This transformation has gradually shifted the T\&L approach in IPTs to enter the information technology era more rapidly (Chen Hsieh, Wu, \& Marek, 2017). Past studies also acknowledged one of the innovations in T\&L with the method of Blended Learning that is a combination of the conventional learning model with online learning. Mosa, Yoo, and Sheets (2011) emphasised that this blended learning pattern comprises two main elements, namely classroom learning with online learning that uses the internet network by including online media in learning programs, while at the same time maintaining open meetings and approaches other traditional in T\&L (MacDonald, 2003; Cho \& Lim, 2013; Stapa \& Muhammad, 2019, Zehra Oczinar et al., 2020). Self-learning with the notion of the blended learning model has become a pedagogical method in today's IPT. The teaching team is no longer a communicator of information to students. Instead, students strive and act actively in obtaining information and knowledge. Hence, it educates students to become self-regulated learners when the learning process is student-centred using experience as a guide to carry out the T\&L process.

The progress of world technology using the internet has also been identified as changing its educational landscape. Conventional T\&L has been combined and will be replaced with the latest technology methods that are more interactive and engaging. E-Learning is now a central T\&L platform for primary, secondary schools and IPT. The studies on e-Learning have produced the following findings: received good acceptance and response from students; easy to use in the learning process and can increase the level of productivity; have a positive impact on students (Agatha F. Umbit \& Muhamad Suhaimi Taat, 2016; Maria Joseph Israel, 2015). E-learning is acknowledged to increase students' motivation and involvement in lessons and make them able to learn independently. Besides, MOOC also can offer good material in terms of videos, assignments, quizzes, and an interface and structure that attracts many users to participate (Nabila et al., 2017). Although MOOCs have been found to promote teaching and increase student engagement, many past studies proved that students' readiness to use MOOCs is still moderate. The study's findings determined that the source of internet/wifi coverage is a significant obstacle to the use of MOOC in the teaching and learning process even though students are committed and driven to use MOOC. Mariyam Altalhi 
(2021) also proved that the acceptance of MOOC as a learning instrument remained low, which is perceived as an entertainment tool rather than an academic tool, particularly in developing countries.

The fast growth of multimedia applications in education has also produced T\&L with the concept of edutainment which is a combination of education \& entertainment (Jamalludin \& Zaidatun, 2000). Nur Aisyah et al. (2012) explained that developments in multimedia technology empowers more excellent opportunities in changing the way we learn, acquire and apply information in science. Multimedia also supports educators to apply various teaching techniques, while students are allowed to participate more actively in a learning session (Jamalludin \& Zaidatun, 2003; Zamri \& Nur Aisyah, 2011). NorHayati Che Hat et al. (2013) also demonstrated that animation is fit to be practised to teach Arabic and attract students to master it. It confirms that visual T\&L has a genuine impact on students (Jamal Raiyn, 2016) and leaves a positive impression on their interest, understanding and motivation (Noor Fadzilah et al. 2017). Multimedia can devise a learning environment that is more user-friendly compared to conventional methods that are only guided by textbooks. Thus, educational technology development enables an increase in educators' creativity to ensure that T\&L in all fields of study is upgraded in line with current developments.

Online T\&L has also been identified enriching the diversity of T\&L methods by educators. COVID-19 abrupt hit affected T\&L in the middle of the semester has proven that mobile technology in learning known as m-learning (mobile learning) emerged significantly as an alternative method that helps students with online T\&L. Mobile learning means taking place when the learner is not at a set, predetermined location or the learner 'takes advantage of the learning opportunities provided by mobile technologies' (O'Malley et al., 2003). Mobile Learning is about learner mobility (Kukulska \& Traxler, 2005), which means learning can happen anywhere, anytime (Kukulska, 2013). These excellent characteristics can solve the problem of traditional teaching method and time constraints. Earlier studies have documented the ability of WhatsApp and Telegram to help students master learning outcomes. Chokri (2010) in his study at Taibah University, Saudi Arabia on two target groups of students determined that the group exposed to additional learning through WhatsApp application (70\% face-to-face $+30 \%$ discussion via WhatsApp) managed to obtain higher grade marks. They were positive in exploring and sharing information and finding solutions related to learning compared to groups that follow conventional and face-to-face learning. Similarly, for the study with WhatsApp and Telegram (Syed Lamsah Syed Chear, 2017), which reviewed students' readiness and ability to follow T\&L through this platform in private universities, it also emphasised its efficiency to help students master learning outcomes. The conclusion also implied that students were not being exposed to m-learning, but they were ready to learn it, and these platforms were found to possess a positive potential and ability to improve the image of the institution and marketability of graduates.

Online T\&L has also proven to impact appreciating the constructivist learning theory approach and realising Lifelong Learning (PSH) skills among students. These skills become the critical skills in 21st Century Skills that need to be mastered by every student to succeed in this challenging century. These skills require them to determine what needs to be learned, find information or materials to learn, own self-learning skills, be independent, motivated, and reflect on their learning by doing selfassessment or other means. This new norm has also recognised student-centred T\&L as outlined by KPT previously based on student-based learning and student-centred learning. It was to ensure the country's young generation is appropriately and independently educated. It follows modern world developments in completing the Industrial Revolution 4.0 students' needs; they need to be selfregulated learners no longer waiting to be spoon-fed by teachers or lecturers who now play more roles as mentors and a guide by the side no longer as a sage on the stage.

PSH or Longlife Learning among university students is also affected by COVID-19, which empowers them appreciating the skills that need to be mastered to prepare them for the job market and learning ways to survive after graduation. Students no longer rely solely on lecturers as a source of knowledge. Nonetheless, they need to organise their learning schedule, find learning materials other than those given by lecturers, arrange discussion time for group assignments, determine the closing date of the breakdown of group work to be completed before the closing date, and make 
various decisions. These tasks require problem-solving skills in facing unstable or weak internet problems, task group members without internet access, laptops and problem speakers. Students' thinking skills must also be active to be mobilised at a high level of thinking. It is not easy to build PSH skills, but COVID-19 and MCO have allowed students to hone these skills that must be prepared in facing online T\&L survival and life.

In addition to the views and positive effects observed from the relevant writing and research reviews, the implementation of online T\&L still has its limitations. As revealed by the Ministry of Education or KPM, limited telecommunication access is one of them. It concerns the effectiveness of home-based learning, and it is quite limited when compared to face-to-face methods. Students have difficulty achieving a minimum level of mastery in each subject followed, will affect students' interest and motivation to continue teaching and learning, students' relationship with the school will also be affected because they are isolated from the school environment for an extended period (Mohd Radzi Jidin, 2020).

The main element of online T\&L constraints involves internet accessibility with three situations. These situations are good student location and stable internet access, low and unstable internet access and no internet access or fragile access. This issue worsens with the lack of smart digital devices due to the inability of families to provide gadgets such as personal computers and smartphones and the attitudes and motivations of students who are still at the level of conventional thinking sets that still need teachers and lecturers to motivate them. Students are also still in the selfdirected learner zone and are not yet fully prepared to become self-regulated learners and are still in the process of adapting to online T\&L situations and learning from home. Evidence from studies among undergraduate students during the COVID-19 semester revealed that they have readiness in terms of knowledge and skills to use technology online but lack readiness in terms of the latest personal computer equipment as well as internet coverage plan and internet access (Samsiah Abdul Hamid \& Rohani Hamzah, 2020). Therefore, further research on the effectiveness of online T\&L which is still implemented in various aspects is beneficial planning and action by those responsible for dealing in with it to afford the best and quality services to national education because COVID-19 is not a barrier but holds hidden wisdom for the country to move forward with the freshest technology.

\section{Methods}

This case study used a questionnaire to collect research information from 133 students of Diploma in Fisheries program, Universiti Malaysia Terengganu, for the first semester of 2020-21 academic session. Questionnaire instruments were developed with adaptations of several instruments related to various aspects of online T\&L while the COVID-19 pandemic hits the world (KPM, 2020; UMT, 2020; Samsiah \& Rohani, 2020; Demuyakor, 2020; Bączek, Zagańczyk-Bączek, Szpringer, Jaroszyński, \& Wożakowska-Kapłon, 2020; Martin, Stamper \& Flowers, 2020). The questionnaire consisted of four sections; Part A: Student Information; Part B: Device / Gadget / Internet Access Information for Online T\&L; Part C: Online E-Learning Access Information; and Part D: Student Readiness Information to Face T\&L Online. Only part D uses eleven 5-point Likert scale question items. The questionnaire was formed using Google Forms and delivered to students through sharing links to their WhatsApp group during week 14 at the end of their first semester of study. One week was given to ensure no pressure on them in filling out the questionnaire answers.

\section{Findings and Discussions}

\subsection{Background of Information and Availability of Student Online Learning Infrastructure}

The study results have obtained information related to the background of students and the availability of digital device equipment, internet access, and access to the e-Learning platform as 
follows.

i. Student Background Information

A sum of 133 out of 137 students of the Diploma in Fisheries (DP) from the first semester 2020-21 session responded. Gender information data showed 40.9\% males and 59.1\% females. All of them were recent SPM holder (Sijil Pelajaran Malaysia) from the Faculty of Fisheries and Food Science; studying Diploma in Fisheries courses; year one and semester one students. They have followed the initial T\&L in their hometown from 12 July - 31 July 2020 (Weeks 1-3) and starting 9 August 2020 (Week 4), the students were in UMT campus. All of them were in the Residential College attending online lectures. They were divided into three lecture groups, namely Group 1:46 students; Group 2: 46 students and Group 3:45 students.

ii. Device Information and Internet Access for Online T\&L

Of the 133 respondents, $74.4 \%$ used laptops; $22.6 \%$ used mobile phones, and the remaining $3 \%$ used desktop computers. It suggested that the devices used for the most critical T\&L were laptops and mobile phones while desktop computers, there was still a handful that used them. Overall, $97 \%$ of students could own their devices. Only $3 \%$ shared them due to financial constraints and yet sharing with family members. Among the students who owned this device, almost half of them, 51.1\% admitted to being very skilled in using it, and the remaining $48.1 \%$ were less skilled, and o.8\% were not skilled at all in using it. The implications impact attending online lecture sessions in terms of technical problems encountered; accessing to perform assignments when directed by lecturers; group discussions; applying specific apps to perform tasks and the like.

In the context of internet access in their homes, $86.5 \%$ had internet access, and $13.5 \%$ had no internet access. Meaning, students need to strive to find internet access areas to follow T\&L. Internet access indicated most students (44.4\%) used service providers of Digi, Celcom, U-Mobile, TM and Maxis mobile data packages; 30.1\% used hotspots and wifi; $19.5 \%$ used Unifi, and 6\% used Streamyx and YES. This situation showed the variety of options for the use of internet service provider packages used according to the ability and comfort and the speed of service provided by the package provider.

While at home, students' internet access level indicated (9.8\%) reached a very fast level. The majority reached fast (43.6\%) and medium (42.1\%) levels; only $4.5 \%$ experienced slow internet access. Nevertheless, their internet access while at the Residential College showed $13.5 \%$ weak; a majority of $40.6 \%$ experienced fast speed, and $37.6 \%$ experienced medium speed; in addition to only $8.3 \%$ experienced very fast internet access. It meant that the speed of internet access in Residential Colleges in particular and the UMT campus in general needs to be improved as a result of these findings. The focus on low-achieving access needs to be identified and examined so that students can enjoy the best access no matter where they are on UMT campus so that their studies experiencing smooth internet service.

iii. Online E-Learning Access Information

All students of Diploma in Fisheries at UMT have been provided with the online e-Learning platform WADI in My-Nemo students that can be accessed at any time for each course taken. Each lecturer has its course platform to display teaching and learning materials and activities planned for each semester. This e-Learning platform is complete for lecturers to upload materials, activities, perform lectures and various other tasks required. If properly utilised, this platform can be the best means to execute online T\&L provided the internet access line is also smooth and widely used.

Findings showed that $97.7 \%$ of students had no problem uploading and downloading the required materials and information. There were no internet access issues in this case. Only a handful (12.2\%) had trouble navigating this platform due to the long and time-consuming loading cycle. These affected students' efforts to browse WADI as a T\&L platform. $64.7 \%$ of students were found to be diligent in browsing it several times a day to take advantage of the lecturers' knowledge. $18 \%$ took 
the initiative to open it once daily as a routine, and the remaining $15 \%$ visited the portal several times a week. Some students did not prioritise this platform by browsing the portal for once a week and only a few times a month. The WADI platform should be made a priority among students for each of their courses. This meant that universities, schools, and even lecturers also need to make the WADI platform for diploma students a mandatory access to implement T\&L. Otherwise, it will be an irrelevant platform. Students used to access to WADI e-Learning for specific purposes in the following order:

1. Browse notes uploaded by lecturers $(92.5 \%)$

2. Download the notes $(89.5 \%)$

3. Perform Online test $(86.5 \%)$

4. Answer assignment questions $(85.7 \%)$

5. Answer quiz questions (59.4\%)

6. Attend Forum / Chat / Webex F2F Synchronous / Webex F2F Asynchronous (42.9\%)

7. Sit for Final examination (29.3\%)

8. Submit Assignments (3\%)

Overall, the lecturers' activities mentioned above are routine in T\&L to meet the needs of blended learning initially. However, after the hit of COVID-19 pandemic, this platform should be upgraded and re-used to meet the demands of online learning, which will be the new norm in national education. WADI can be used as a single platform for diploma students in appreciating online learning if improvements that make it easier to use, especially from a technical aspect are given attention and the steady internet access provided. The initiatives to upgrade the WADI platform should be highlighted to make it the only platform for online T\&L so that students will feel the importance of overcoming the new norms of online T\&L. If there are too many platform usage varieties for T\&L, it also makes it difficult for students and even lecturers to use this digital communication.

\subsection{Student Readiness Information to Face Online TEL}

Generally, Diploma students had a high level of readiness to experience online T\&L. It was based on their experience using computers at the school level and the information technology age generation known as the Net generation (Gen-Z). It helped them prepare to master real skills in this new online T\&L norm. Only a few students were still hesitant and less confident in facing this situation due to a lack of experience using computers and gadgets due to low-income family background and a low level of computer literacy.

Students already had the foundation to master the skills in managing document administration in terms of opening files, writing and editing, and managing document files technically. Majority of them $(90 \%)$ were confident that there was no problem implementing it than a few who knew the basic usage but were still less efficient at doing it. This inefficiency was also due to the lack of opportunities to use computers widely because they did not own theirs and went through computer sharing sessions with family members.

Following T\&L through the e-Learning platform hinted the readiness of a small percentage of students. It proved that $(9 \%)$ technically still needed help and guidance to teach them to master technical skills in surfing the e-Learning platform to become smooth as a new daily routine in their studies. Majority of other students have already mastered and were technically efficient to browse eLearning activities such as finding lecture materials, quizzes and the like that have been uploaded by lecturers and can download the material; also upload assignments and materials to the e-Learning system.

Nonetheless, in terms of operating online for face-to-face (Synchronous) lectures and online group discussions face-to-face (Asynchronous) using the Webex or Google Meet platform, the students still needed much training. $20 \%$ of them were still unfamiliar with the platform, which was still new to them in this era of pandemics compared to face-to-face lectures traditionally practised. 
The new norm of online T\&L required them to adapt it into a habit. However, $80 \%$ of those who were computer literate and those who quickly mastered these technological skills were ready and happy to explore the new era of T\&L online. They were competing and helping each other to master this digital application. It was evident in their close cooperation during online lectures and their WhatsApp group chat.

Students were also highly confident in being able to act on their own and help in groups. These tasks were focusing attention to learning through various platforms such as videos, online conferences, written instructions, and reading online materials, be able to foster discipline and be punctual for online lectures until the end, take note of the deadlines of all tasks and set goals to achieve them, can act on their own and to have discussions and help with friends to ensure that online T\&L can run smoothly until the end of the semester. It also indicated that the new norms of online T\&L had nurtured students to become self-regulated learners in managing their learning curves. Their confidence has been manifested through the achievements they have accomplished through individual, group assignments and the assessments they have gone through until the end of semester 1. Their achievements were of 137 people, marks A (108); A- (20); B + (8) and B (1) and no student failed.

\subsection{Impact of Online TEL on the National Education Agenda}

The COVID-19 pandemic affected the national education agenda at the primary, secondary and higher education institutions that should be viewed positively to continue to provide the best and quality services and relevant to current developments. Currently, in 2021, the COVID-19 crisis is still daunting until the country implemented PKP 2.o. The educational agenda can not be continued faceto-face until a date agreed upon is suitable and safe. Therefore, all relevant parties are working hard to ensure that proactive and most appropriate action is taken to ensure that every country's level of education suffers from zero dropouts. It is not easy to realise it, but nothing is impossible to implement if all parties' close cooperation is gathered and united for the continuity of education of the nation.

The results of the study have had an impact on the following aspects that must be given attention and immediate action. Among them are:

1. Online T\&L and Home-Based Learning

The new norms of online T\&L led to transforming the T\&L atmosphere based on the information and digital technology literacy with a flexible and interactive approach that necessitates continuous improvement to guarantee all students achieving effective learning outcomes. The impact will lead to structural changes and continuous delivery of the academic program curriculum (Mohamad Kadim Suaidi, 2020). Academic programs need assessment and strategy planning to be streamlined in line with the online T\&L approach. Curriculum content requires more flexible elements to ensure that the T\&L process can be continued in any unforeseen circumstances that the country will face. Alternative and holistic assessments should be planned without compromising graduates' quality in the face of future realities.

Addressing the COVID-19 pandemic semester among educators has led to a shift in mindset by imparting knowledge to students in line with technological developments. Educators in the 21st century are responsible for forming and guiding students including being resilient, flexible, lifelong learning, applying higher order thinking skills and not spoon-feeding them with T\&L materials as usual while encouraging their participation in discussions and communication between each other. Although the implementation of T\&L continued until the end of the semester, the constraints encountered including, students from family backgrounds who were not able to provide equipment and online learning support environments such as the absence of mobile phones, laptops, tablets, and televisions; even sharing equipment with family members with limited usage time. The implications will lead 
to dropouts in their learning and even lead to emotional effects such as embarrassment and frustration that can lead to family conflicts and depression. Therefore, all parties, including educators, IPT management and schools, parents, stakeholders as well as MOE and the Government in particular, need to take immediate and severe action to identify the needs, strategies and appropriate actions to formulate the direction and latest policies of T\&L new national norms to ensure education is implemented with current changes and needs.

2. Internet Accessibility and Digital Gap

The main challenge of national education in realising online T\&L has been identified as internet accessibility. The National Statistics Department in 2019 showed 90.1 per cent of households have internet access, but the issue of unstable internet is very critical, especially in rural areas. The benefits of online T\&L can only be enjoyed if internet access can be widely enjoyed in the city, rural and outskirt areas. However, three situations were identified as obstacles, namely good student location and stable internet access, low and unstable internet access, no internet access or fragile access. It worsened by the lack of smart digital devices due to families' inability to provide gadgets such as personal computers and smartphones leading to large gaps in the digital gap between students to access materials through online platforms. Besides, in rural and inland areas such as Indigenous villages in Peninsular Malaysia, Sabah and Sarawak, internet connection is minimal; some villages do not have access to electricity or limited use at night. Although Malaysia is improving its overall internet penetration rate, the digital divide gap is still significant between urban and rural areas.

Therefore, this challenge needs to be given the utmost attention that is the basis for transforming the implementation of digitalisation of national education technology. Among the appropriate strategies to meet this need include providing device ownership promotion initiatives such as grants and loan schemes with tax relief especially to low-income families, delivering support from the private sector and non-governmental organisations (NGOs) to donate new or used computers for distribution to schools, doubling the availability of highspeed internet access among all walks of life through the implementation of the National Optical Fiber and Connectivity Plan (NFCP), and executing the role of telecommunication companies in providing free additional data for educators, students and even parents in facing current challenges (Hawati Abdul Hamid \& Jarud mined Romadan Khalidi, 2020). The cooperation of various government and private agencies and NGOs and even the people's leaders should sacrifice for the people's benefit, especially the younger generation who still need the education to survive their lives. The parties concerned should provide strategic assistance and change the importance of profit in helping the community and society when facing this pandemic crisis.

3. Student Self-Motivation

Online T\&L has a direct impact on the development of students' self-motivation at all levels of education. Whether it is viewed positively or negatively, it depends on the perception of personal acceptance. The application capabilities and adaptation of information technology in terms of device hardware and online educational application exploration have gained increasing value among them, even though only a few still need technical support and assistance. However, this pandemic situation has boosted students' skills, abilities and readiness in surfing T\&L online and honing their talents and skills to face the latest modern world.

Students have well received Synchronous online face-to-face and Asynchronous online T\&L platform for various forms of planned activities. Although there were constraints, they tried to overcome with various alternatives. There were no problems in group collaboration and lecturers, but continuous improvement needs to be taken so that T\&L improves. Awareness of self-discipline control arose. They learned to comply with lecture time, increase the current focus of T\&L with a different environment than the previous situation, stay online to finish an hour or two of lectures, be independent in performing individual or group tasks, 
respond online to meet activity needs; and mobilise higher-order thinking skills (Chew Fong Peng \& Shashipriya Nadaraja, 2014) to make decisions to solve problems in facing real problems virtually during learning sessions.

These actions and processes that students went through indirectly prepare them to become selfregulated learners who can think, act and control the situation independently in the face of T\&L. Students are now self-directed learners who act with instructions and guidance by the lecturer compared to the previous ones. The implications of adult-level learning with andragogy approach and constructivism theory can be practised more clearly through experience and action. Therefore, in addressing the real situation of change in T\&L approaches and methods and complementing the learning theory framework, some actions need to be administered. These actions include strengthening knowledge through workshops to improve educator professionalism, and sharing scientific discourse as implemented by most higher learning institutions to establish relevant and current new knowledge, in particular, to support the generation of educators at the senior level, and advance knowledge to the generation juniors educators.

\section{Conclusion}

It is evident that the country's educational landscape has been affected by the COVID-19 pandemic, which has prompted the transformation of information and communication technology and the digitalisation shift in virtual learning. The innovative and high-tech education ecosystem has been accelerated in line with the education agenda in meeting the needs of RI 4.o. Not only educators and students but also parents and the community are motivated to take advantage of this change. Online T\&L has become a significant platform in the country's latest education agenda with the need for internet accessibility and compulsory smart digital device equipment among students. On the other hand, internet access and access constraints in urban and rural areas, internet coverage plans, and digital devices' availability is a critical challenge that needs immediate attention and action to overcome. Nevertheless, with the strategic alliance of various parties, including educational institutions, government and private agencies, NGOs, and even the people's leaders themselves, these constraints can be handled competently to advance education into the epoch of global education that is technology-motivated and digital-driven.

\section{Acknowledgement}

This work is part of a research conducted related to teaching and learning during Covid-19 pandemic and financially supported by Universiti Malaysia Terengganu, Malaysia.

\section{References}

Abdul Halim Abdullah. 2020. 'COVID-19 Buka Mata Warga Pendidik Dan Pelajar'. Rencana, Komentar. bhrencana@bh.com.my.28.3.2020.

Afandi Ahmad. 2020. 'Cabaran COVID-19: Tanggungjawab Pensyarah Dan Pelajar Di Universiti'. Berita News UTHM Portal.

Agatha F. Umbit \& Muhamad Suhaimi Taat. 2016. Faktor-Faktor Yang Mempengaruhi Penerimaan E-Pembelajaran Dalam Kalangan Pelajar Di Institut Pendidikan guru di Sarawak. Jurnal Penyelidikan IPGK Bil.13, 1-14.

Bączek, M., Zagańczyk-Bączek, M., Szpringer, M., Jaroszyński, A.Kapłon, B. 2020. Students' perception of online learning during the COVID-19 pandemic: a survey study of Polish medical students. Research Square, 1-14. doi.org/10.21203/rs.3.rs-41178/v1.

Chen Hsieh, J. S., Wu, W.-C. V., \& Marek, M. W. (2017). Using the flipped classroom to enhance EFL learning. Computer Assisted Language Learning, 30, 1-2, 1-21. doi:10.1080/o9588221.2015.1111910.

Chew Fong Peng \& Shashipriya Nadaraja. 2014. Pelaksanaan Kemahiran Berfikir Kreatif Dan Kritis Dalam Pengajaran Dan Pembelajaran Komsas Di Sekolah Menengah. Jurnal Pendidikan Bahasa Melayu. 4 (2): 10-24. 
Cikgu Hailmi. 2020. E-Pembelajaran: Peranan Kerajaan, Guru Dan Ibu Bapa. Blog Cikgu Hailmi. Berita Utama/Rencana. Suara Blogger. 21.4.2020.

Cho, C. W. \& Lim, L. K. S. E. 2013. Measuring the effectiveness od blended learning environment: A case study in Malaysia. Education Information Technology. DOI 10.1007/s10639-013-9293-5.

Chokri, B. 2010. The effectiveness of WhatsApp mobile learning activities guided by activity theory on students' knowledge management. Contemporary Educational Technology 6(3): 221-238.

Demuyakor, J. 2020. Coronavirus (COVID-19) and Online Learning in Higher Institutions of Education: A Survey of the Perceptions of Ghanaian International Students in China. Online Journal of Communication and Media Technologies, 10, 3, e202018. https://doi.org/10.29333/ojcmt/8286

Ehwan Ngadi. 2020. COVID19: Implikasi Pengajaran dan Pembelajaran Atas Talian. Risalah USIM.

Hawati Abdul Hamid \& Jarud Romadan Khalidi. 2020. Covid-19: Merapatkan Jurang Pembelajaran Pelajar Sekolah. The Malaysian Insight. 4 Mei 2020.

H.A.Rahman, A, Ibrahim W, Ali, N (2012). 'Islamic concept of social justice in the twentieth century'. Advances in Natural and Applied Sciences. 6:8. 1423-1427.

Jamal Raiyn. 2016. The Role of Visual Learning in Improving Students' High-Order Thinking Skills. Journal of Education and Practice. 7(24): 115-121.

Jamaludin, Z. \& Sani, A. M. (2012). E-Learning Champion: Fungsi, Tugas Dan Petunjuk Prestasi. Buletin MEIPTA. Pusat Pengajaran Pembelajaran Universiti. Universiti Utara.

Jamalludin \& Zaidatun. 200o. Pengenalan kepada Multimedia. Kuala Lumpur: Venton Publishing.

Jamalludin Harun \& Zaidatun Tasir. 2003. Multimedia dalam Pendidikan. Pahang: PTS Publications \& Distributors Sdn. Bhd.

Kementerian Pendidikan Malaysia. 2013. Pelan Pembangunan Pendidikan Malaysia 2013- 2025. Putrajaya: Bahagian Pembangunan Kurikulum.

Kementerian Pendidikan Malaysia. 2015. Pelan Pembangunan Pendidikan Malaysia 2015- 2025. Putrajaya: KPM.

Kementerian Pendidikan Malaysia. 2020. The Determinants of E-Learning Readiness Among Teachers in Malaysian Public Schools. Putrajaya: KPM.

Kukulska-Hulme, A., \& Traxler, J. 2005. Mobile Teaching and Learning. Mobile Learning: A Handbook for Educators and Trainers, 42-61. http://doi.org/10.1111/j.1467-8527.2009.437_6.

Kukulska-Hulme, A. 2013. Mobile-assisted language learning. In C. Chapelle (Ed.), The encyclopedia of applied linguistics (pp. 3701-3709). New York: Wiley.

Macdonald, D. 2003. Curriculum change and the post-modern world: Is the school curriculum-reform movement an anachronism? Journal of Curriculum Studies, 35(2), 139-149.

Maria Joseph Israel. 2015. Effectiveness of Integrating MOOCs in Traditional Classrooms for Undergraduate Students. International Review of Research in Open Learning and Distributed Learning. 16(5): 102-118.

Martin, F., Stamper, B., \& Flowers, C. 2020. Examining student perception of their readiness for online learning: Importance and confidence. Online Learning, 24(2), 38-58. doi.org/10.24059/olj.v24i2.2053

Mariyam Altalhi. 2021. Towards Understanding the Students' Acceptance of MOOCs: A Unified Theory of Acceptance and Use of Technology (UTAUT). International Journal of Emerging Technologies in Learning. iJET - Vol. 16, No. 02, 2021. 237-253. http://www.i-jet.org; https://doi.org/10.3991/ijet.v16io2.13639

Mohamad Kadim Suaidi. 2020. Pendidikan Tinggi Pasca Covid-19: Antara Norma Baharu Dan Hala Tuju. Bernama. 12.6.2020

Mohan Rathakrishnan. 2020. COVID-19 Ubah Pengajaran Dan Pembelajaran Dari Rumah. Rencana, Komentar. bhrencana@bh.com.my.14.7.2020.

Mohd Fuad Mohd Salleh \& Supyan Hussin. 2008. e-Learning Issues in Malaysian Higher Education. Skudai: UTM Press.

Mohd Radzi Jidin (dlm Rohaniza Idris et al.) 2020. T\&L Dalam Talian Kurang Berkesan. Rencana, Komentar. bhrencana@bh.com.my. 1 Julai 2020

Mosa, A., Yoo, I., \& Sheets, L. 2011. A Systematic Review of Healthcare Applications for Smartphones. BMC Medical Informatics and Decision Making, 12, 67. doi: 10. 1186/ 1472-6947-12-67.

Muzaffar Syah Mallow. 2020. Tinta Minda-T\&L Dalam Talian. Bernama. 29.06.2020.

Noor Fadzilah Ab Rahman, Rafiza Kasbun, NurKaliza Kahlid, Siti Azrehan Aziz \& Nur

Hashima Mohamed. 2017. Penggunaan Aplikasi Visual Dalam Pembelajaran Konsep

Dan Asas Pengaturcaraan. National Pre University Seminar (NpreUS2017).

Norasmahani Hj Nor. 2015 (in Nur Fadilah Abdul Basit, Maimun Aqsha Lubis, Harun Baharudin \& Nurul Akhma Yahya). Pembelajaran Interaktif E-Learning Mencorakkan Kemahiran Berfikir Aras Tinggi. Proceeding The 7th International Workshop And Conference Of Asean Studies On Islamic And Arabic Education And Civilization (Poltan-UKM-Polimed). 3 June 2015. 
Nor Aziah Abdul Aziz Mohd Taufik Hj Ahmed. 2016. E-Pembelajaran Dalam Pengajaran Dan Pembelajaran Bahasa Melayu Di IPG Kampus Ipoh. Jurnal Penyelidikan Dedikasi Jilid 11, 2016.

Nor Hayati Che Hat, Shaferul Hafes Sha'ari \& Mohd Fauzi Abdul Hamid. 2013. Persepsi pelajar terhadap penggunaan animasi dalam pembelajaran bahasa Arab. Jurnal Teknologi, 63(1): 25-29. Skudai: Penerbit Universiti Teknologi Malaysia Press.

Nor Hidayati Mokhtar. 2020. Pembelajaran Atas Talian Untuk Pembelajaran Sepanjang Hayat. Bernama. 7.4.2020.

Nur Aisyah Mohamad Nor, Zamri Mahamod, Afendi Mahat \& Mohamed Amin Embi. 2012. Persepsi pelajar terhadap aplikasi perisian multimedia dalam pembelajaran komsas Bahasa Melayu tingkatan 1. Jurnal Pendidikan Bahasa Melayu, 2(1): 1-16. Bangi: Universiti Kebangsaan Malaysia.

Nurulrabihah Mat Noh, Saedah Siraj, Siti Hajar Halili, Mohd Ridhuan Mohd Jamil, \& Zaharah Husin. 2019. Aplikasi teknik Fuzzy Delphi terhadap keperluan elemen teknologi sebagai wadah dalam pembelajaran berasaskan pemikiran reka bentuk. Asia Pacific Journal of Educators and Education, 34, 129-151.

https://doi.org/10.21315/apjee2019.34.7.

O'Malley, C., Vavoula, G., Glew, J., Taylor, J., Sharples, M. \& Lefrere, P. 2003. Guidelines for learning/teaching/tutoring in a mobile environment. Mobile learning project deliverable. Available from http://www.mobilearn.org/download/results/guidelines.pdf

Razali, N. A., Norman, H., Rahman, M. J. A. \& Jamilluddin, N. A. 2017. Pendekatan

Pembelajaran dalam Persekitaran Massive Open Online Courses bagi Peringkat

Pengajian Tinggi. Seminar Serantau 2017, Universiti Kebangsaan Malaysia. https://meipta.files.wordpress.com/2012/o2/buletin-meipta-bil-1-2012-vb-print.pdf

Rohaniza Idris; Mohd Iskandar Ibrahim dan Zanariah Abd Mutalib. 2020. T\&L Dalam Talian Kurang Berkesan. Rencana, Komentar. bhrencana@bh.com.my. 1 Julai 2020.

Samsiah Abdul Hamid \& Rohani Hamzah. 2020. How Ready Were Malaysian Undergraduates for the Sudden Online Classes during the COVID-19 Pandemic? Seminar Antarabangsa MADANI 2020, Pusat Pendidikan Asas dan Lanjutan. 1-2 Disember 2020.

Syed Lamsah Syed Chear. 2017. Pengajaran dan Pembelajaran Melalui Aplikasi Whatsapp dan Telegram di Universiti Swasta. Jurnal Pendidikan Malaysia. 42(2)(2017): 87-97. DOI: http://dx.doi.org/10.17576/JPEN2017-42.02-02.

Stapa, M. A. \& Muhammad, N. 2019. The use of addie model for designing blended learning application at vocational colleges in Malaysia. Asia-Pacific Journal of Information Technology and Multimedia, 8, 1, 49-62.

Tuan Buqhairah Tuan Muhamad Adnan. 2020. 'Kurang berkesan' - Ini kata Menteri Kanan Pendidikan berkenaan T\&L Online. GPS BESTARI-Portal Pilihan Guru Pelajar Sekolah. 2 Julai 2020.

UNESCO. 2020. COVID-19 educational disruption and response. Retrieved from https://en.unesco.org/covidig/educationresponse 202013 March

Universiti Malaysia Terengganu. 2020. Impak Pembelajaran Dalam Talian Terhadap Prestasi dan Kesediaan Pelajar Mengikuti Pembelajaran Dalam Talian Semasa Pandemik COVID-19 Di UMT. PPAK, UMT.

Yasmin Saw. 2020. Pembelajaran Dalam Talian Pada Masa Krisis Covid-19. The Malaysian Insight. 16 Apr 2020.

Yuliya Murzo \& Natalia Chuvileva. 2021. Use of Information Technologies in Developing Foreign Language Competence for Professional Interaction of Undergraduate and Postgraduate Students Specializing in Mineral Resources. International Journal of Emerging Technologies in Learning. iJET - Vol. 16, No. $03,2021$. 144-153. http://www.i-jet.org; https://doi.org/10.3991/inet.v16io3.17875

Zamri Mahamod \& Nur Aisyah Mohamad Noor. 2011. Persepsi guru tentang penggunaan aplikasi multimedia dalam pengajaran komponen sastera Bahasa Melayu. GEMA Online Journal of Language Studies, 11 (3): 163177. Bangi: Universiti Kebangsaan Malaysia.

Zehra Oczinar et al., Regina G. Sakhieva, Elena L. Pozharskaya, Olga V. Popova, Mariya V. Melnik \& Valentin V. Matvienko. 2020. Student's Perception of Web 2.o Tools and Educational Applications. International Journal of Emerging Technologies in Learning. iJET - Vol. 15, No. 23, 2020.220-233. http://www.i-jet.org; https://doi.org/10.3991/ijet.v15i23.19065

Zhiyasheva Zhanar Shoraevna, Zhumabayeva Aziya Eleupanovna, Sartayeva Nazgul Tashkenbaevna, Zhamila Zulkarnayeva, Lebedeva Larisa Anatolevna \& Umirbekova Akerke Nurlanbekovna. 2021. Teachers' Views on the Use of Information and Communication Technologies (ICT) in Education Environments. International Journal of Emerging Technologies in Learning. iJET - Vol. 16, No. 03, 2021. 261-273. http://www.i-jet.org; https://doi.org/10.3991/ijet.v16io3.18801 